\title{
Vladimir Mikhailovic Bekhterev (1857-1927): Strange Circumstances Surrounding the Death of the Great Russian Neurologist
}

\author{
Jürg Kesselring \\ Department of Neurology and Neurorehabilitation, Rehabilitation Centre, Valens, Switzerland
}

\section{Key Words}

Bekhterev $\cdot$ Russian neurology $\cdot$ Stalin

\begin{abstract}
The famous Russian neurologist Vladimir Mikhailovic Bekhterev (1857-1927) was ordered to examine Josef Stalin in December 1927 during the First All-Russian Neurological Congress in Moscow. Returning to the Congress after his consultation he told some colleagues that he had 'examined a paranoiac with a dry, small hand'. The next day, Bekhterev died and only his brain was examined postmortem, the body being cremated the same day.
\end{abstract}

Copyright $\odot 2011$ S. Karger AG, Basel

In rheumatology, the name of Bekhterev (Bechterew) is usually associated with ankylosing spondylitis, a chronic progressive auto-immune disease that mainly affects the spine and surrounding structures such as the sacro-iliac joints, the small synovial joints and the edges of the discs, resulting in the so-called 'bamboo spine'.

Bekhterev published first on spondylitis in 1892 in the St. Petersburg medical journal Vrach [1] and a year later a translation in the Neurologisches Centralblatt Leipzig,
'Die Steifigkeit der Wirbelsäule und ihre Verkrümmung als besondere Krankheitsform' ('The rigidity of the spine and its curvature as a special form of disease') [2]. His descriptions, however, do not conform to what is now diagnosed as ankylosing spondylitis, which nevertheless has been described by neurologists [3-5].

Bekhterev was an important Russian neurologist, born on January 20 after the Julian, February 1 after the Gregorian calendar in 1857 in Sorali Vyatka province (fig. 1).

After medical school he spent several years of travelling, primarily working in neurological and psychological institutes in Germany, among others with Paul Flechsig and Wilhelm Wundt in Leipzig, Theodor Meynert in Vienna and with Jean-Martin Charcot at La Salpêtrière in Paris. In this period he wrote numerous neurological articles, especially in German, which he published, for example, in Pflügers Archiv für die gesammte Physiologie des Menschen und der Tiere (Pflüger's Archive for the Entire Physiology of Humans and Animals) and several times in the Neurologisches Centralblatt Leipzig [6-8]. He wrote a great textbook Die Leitungsbahnen im Gehirn und Rückenmark: ein Handbuch für das Studium des Aufbaues und der inneren Verbindungen des Nervensystemes [9] on 'conducting pathways in the brain and spinal cord', which

\section{KARGER}

Fax +4161306 1234 E-Mail karger@karger.ch www.karger.com
(C) 2011 S. Karger AG, Basel

0014-3022/11/0661-0014\$38.00/0

Accessible online at:

www.karger.com/ene
Prof. Jürg Kesselring

Department of Neurology and Neurorehabilitation

Rehabilitation Centre

$\mathrm{CH}-7317$ Valens (Switzerland)

Tel. +41 81303 1408, E-Mail kesselring.klival@ spin.ch 
1

Fig. 1. When Bekhterev was sitting for the sculptor E.A. Block, he modelled himself a head of a suffering boy out of a piece of clay which Block then integrated into his own sculpture. This astonishing combination symbolizes Bekhterev's identification with the suffering of his patients [6].

Fig. 2. Portrait of Bekhterev by Il'ja E. Repin painted in the summer of 1913. Original in the Russian Museum in St. Petersburg; copy by Repin himself in the Bekhterev Museum in the Psychoneurological Institute.

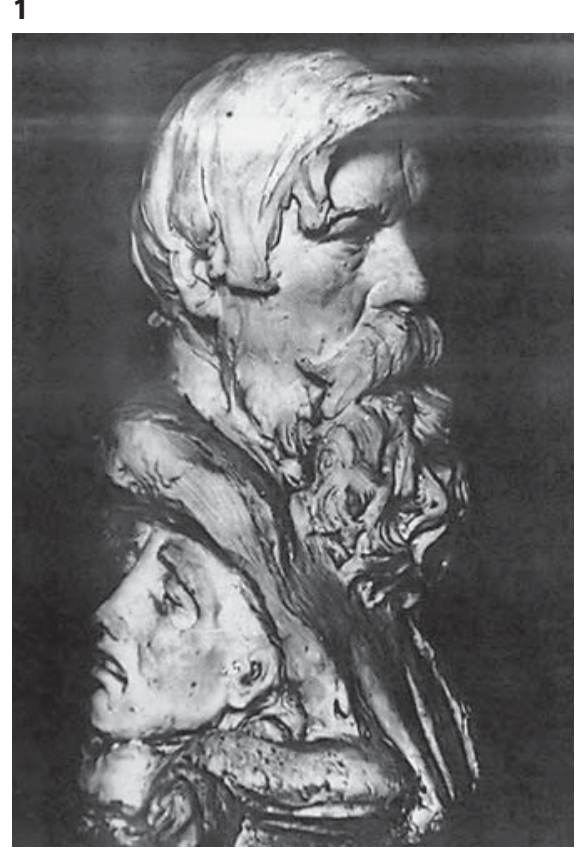

2

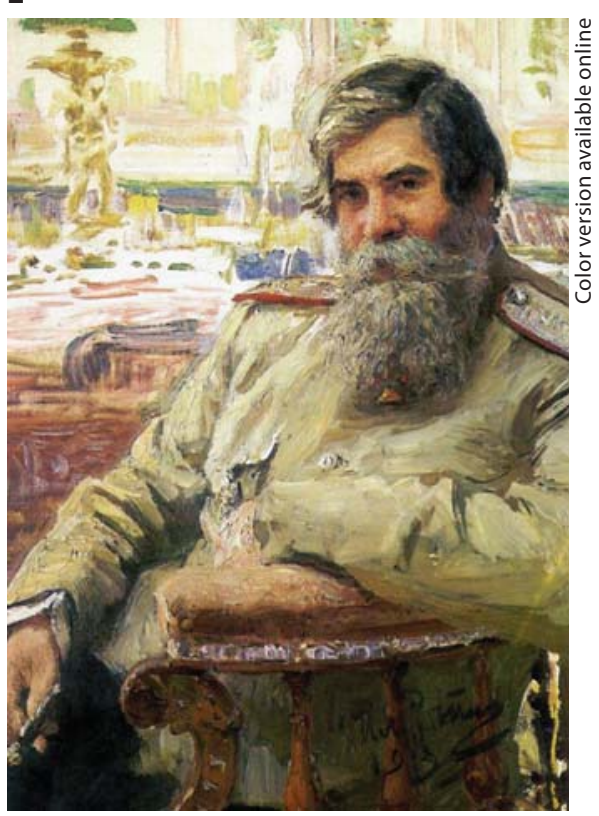

became a standard textbook and earned him the reputation: 'Only two know the mysteries of the brain: God and Bekhterev' (a quotation which occasionally is attributed to Friedrich Wilhelm Theodor Kopsch, 1868-1955, the eminent anatomist).

After his years of travelling Bekhterev was appointed to the chair of neurology at the University of Kazan, Tatarstan, where he founded a neurological school, from which emerged, much later, Alexander Romanovich Luria. A new museum recently opened in Kazan and is devoted to his memory there [10]. In 1905, he founded and led the Psychoneurological Institute in St. Petersburg, which in 1925 was named after him. He was partly in fruitful competition, sometimes in open opposition with Pavlov, who dominated the faculty [11].

Bekhterev was a renowned neurologist, he had also contributed an article to the Festschrift for the great Swiss neurologist (of Russian origin) Constantin von Monakow $[12,13]$ on occasion of his 70th birthday in 1923 in the Swiss Archives of Neurology and Psychiatry. He had also been called to the bedside of Lenin and was co-founder of the First All-Russian Congress of Neurologists and Psychiatry, held in December 1927 in Moscow [14-16] (fig. 2).

Bekhterev was Honorary President of this Congress and in top health condition as various sources attest. A few weeks earlier he had received a telegram from Moscow asking (or rather: ordering) him to quickly come to
Moscow for a neurological examination in the Kremlin [16]. In various newspaper reports and memoirs of the time, as well as in those of the composer Shostakovich [17, 18], it is described that on December 23, 1927, after having lectured on child neurology at the Congress mentioned, Bekhterev went to the Kremlin to examine Stalin [14]. About $3 \mathrm{~h}$ later he came back to the Congress for an important meeting and said to some colleagues there: 'I have just examined a paranoiac with a short, dry hand'. On the same evening he was in the theatre [some sources say it was the Bolshoi Theatre, others speak of Mal'ij (Little Theatre)], and in the break 2 unknown young men approached him and offered him cakes and drinks at the buffet. After returning to his apartment - when in Moscow, he always used to reside with his old friend, the gynaecologist Prof. Plagavoli - violent vomiting started. The next morning his wife called a doctor for consultation, and Prof. Burmin (1872-1954) came and made a diagnosis of 'gastro-enteritis' [19]. Then, on December 24, 1927, two doctors came to his bed uninvited, who were later identified as doctors Klimenkov and Konstantinovski, members of the Secret Service, and later also Mr. R. Rein, a member of the Central Committee, came for a visit. Towards evening Bekhterev lost consciousness, respiration became irregular and blood pressure was dropping. Resuscitation attempts were made in this house ... and in the evening he was dead 'from heart failure ...' [16]. The next day a consultation was convened by 9 profes- 
sors: of notice, Prof. Scherwinski was present, a formerly famous internist who had retired in 1911, the previously mentioned Prof. Burmin, a balneologist was present and also a well-known neuropathologist, Prof. Abriskov. In this consilium it was stated that Bekhterev, just before his death, had wished that no autopsy be performed and that he had only allowed his brain to be removed. The brain removal was carried out by Prof. Il'in, the chief physician of a psychiatric hospital in Moscow, allegedly on the orders of Health Minister Semashko [16]. He declared in a report that Bekhterev's brain was brought 'within $15 \mathrm{~min}$ from the skull into a pot on the table .... It is also recorded that the body of Bekhterev was sent for cremation the same day against the will of the members of his family.

In the year 1927, Bekhterev had had the plan to build a 'Pantheon of Brains' in Leningrad [20]. It is an irony of fate that exactly at the time when the question of the creation of the pantheon had been positively resolved, the initiator of this institution, Bekhterev, died so suddenly ... In 1928, the neuro-anatomical laboratory of the Vogts and their Russian counterparts was re-organized in Moscow as the Moscow Brain Research Institute [20]. It was there where the structured collection and organization of the brains of famous Russians was set up. Bekhterev did not live up to the fulfilling of his plans, but his own brain enriched the collection of the Moscow Institute (with a weight of $1,720 \mathrm{~g}$ !). For a long time scientific investigations of skulls and brains of geniuses went hand in hand with hagiographical celebrations of scientists. Late-eighteenth century anatomists and anthropologists highlighted quantitative parameters such as the size and weight of the brain in order to explain intellectual differences between women and men and Europeans and non-Europeans, geniuses and ordinary persons. Reports about extraordinary brains were part of biographical sketches, mainly delivered in celebratory obituaries [21].

The diagnosis of paranoia in the case of Stalin was, no doubt, well founded (ICD-10 F60.0: paranoid personality disorder; excessive sensitivity to rejection; bearing on slights, suspicion; tendency to distort experiences; neutral or friendly actions of others misinterpreted as hostile or contemptuous; recurring unjustified suspicions regarding sexual fidelity of spouse or sexual partner; contentious and continued insistence on their own rights; inflated self-esteem and frequent, excessive self-absorption). Stalin also had all the signs of what was described recently [22] as 'hubris syndrome'. The neurologist David Owen, a long-standing Member of Parliament in England and twice foreign minister, wrote a book worth reading

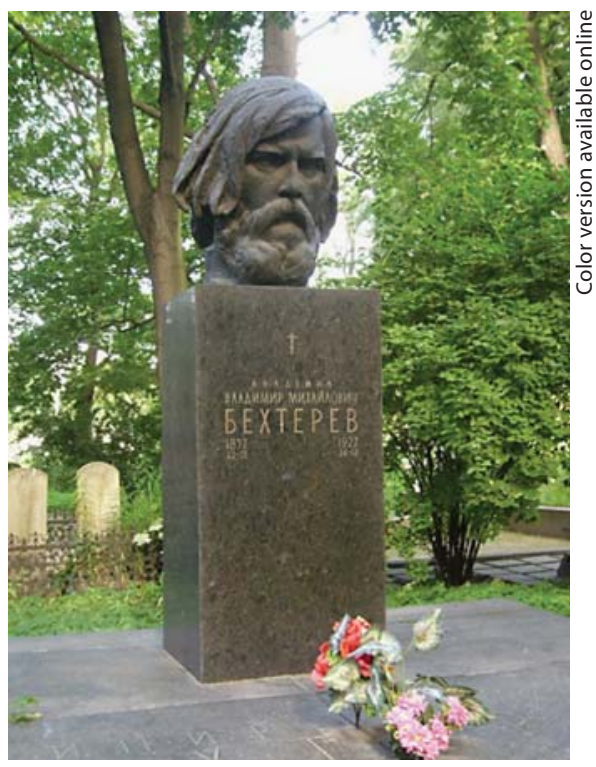

Fig. 3. Tombstone of V.M. Bekhterev in the Volkovo cemetery in St. Petersburg.

on diseases of state leaders in the last 100 years [23]. He also proposed criteria for this hubris syndrome and suggested its relationship with cluster B personality disorders in DSM-IV.

It is not clear what Bekhterev could have meant with the diagnosis of 'small dry hand' for his patient: it is known that Stalin's left hand, probably the whole left arm, was slightly atrophic - his left hand is only rarely seen in pictures and on the few occasions in which it can be seen, it appears clearly smaller, slightly atrophic. On the few occasions where Stalin can be seen on film, he is moving both arms, e.g. when clapping hands or when swinging arms when walking, a certain spasticity is apparent in the left upper limb, so that, in retrospect, syringomyelia seems to me a diagnostic possibility. It is understandable that to confirm or refute such a difficult diagnosis the doctors in Moscow had asked the famous colleague Bekhterev from Leningrad for a consultation. But it was the other diagnosis which he had made aside and for which he most probably had not been asked which caused his premature death.

After his death the name of Bekhterev was hushed up in the Soviet Union; one of his sons was exiled and died soon after his father. His granddaughter, Natalia Petrovna Bekhtereva, later headed the Institute of the $\mathrm{Hu}$ man Brain of the Russian Academy of Sciences in St. Petersburg [24]. She said in an interview that they some- 
times had spoken about the affair of her grandfather in the family, but that it was never clarified. She could only confirm that her grandfather had never been a coward and would have been prepared also to express an unpopular diagnosis.
Much later, during the thaw climate under Khrushchev, or even later in the 70s, Bekhterev was rehabilitated and recognized as one of the great Russian neurologists $[25,26]$. He was honoured in 2007 with a 5-ruble stamp, and in the 1970s, a sculpture was erected on the cemetery in St. Petersburg (fig. 3).

\section{References}

1 Bekhterev VM: Oderevenelast' pozvonochikas iskrivleniemego, kak osabia forma zabolevaniia. Vrach (St Petersburg) 1892;13:899903.

2 Bekhterev VM: Die Steifigkeit der Wirbelsäule und ihre Verkrümmung als besondere Krankheitsform. Neurol Centralbl Leipzig 1893;12:426.

3 Connor B, Marie P: Les rhumatismes déformants. Tribuna Med Paris 1895;27:27-30.

4 Marie P: Sur la spondylose rhizomélique. Rev Méd Paris 1898;18:285-315.

5 Von Strümpell A: Bemerkung über die chronische ankylosirende Entzündung der Wirbelsäule und der Hüftgelenke. Lehrbuch der speciellen Pathologie und Therapie der inneren Krankheiten. Leipzig, Vogel, 1884, vol 2, p 152.

6 Pfrepper R, Pfrepper G, Akimenko MA (eds): Vladimir Michajlovic Bechterev (1857-1927): Neue Materialien zu Leben und Werk. Aachen, Shaker, 2007.

7 Bechterew VM: Über die functionelle Beziehung der unteren Oliven zum Kleinhirn und die Bedeutung derselben für die Erhaltung des Körpergleichgewichtes. Arch Ges Physiol Menschen Thiere 1882;9:257-265.

8 Pfrepper G, Pfrepper R: Publikationen Vladimir M. Bechterevs in deutscher Sprache; in Pfrepper R, Pfrepper G, Akimenko MA (eds): Vladimir Michajlovic Bechterev (1857-1927): Neue Materialien zu Leben und Werk. Aachen, Shaker, 2007, pp 115-168.
9 Von Bechterew W: Die Leitungsbahnen im Gehirn und Rückenmark: ein Handbuch für das Studium des Aufbaues und der inneren Verbindungen des Nervensystemes. Leipzig, Arthur Georgi, 1899.

10 Snamentyie Semljaki Vladimir Michailovic Bechterev. Sbornik statej Elabuga 2007 (Museum's catalogue).

11 Akimenko MA: Vladimir Michajlovic Bechterev. J History Neurosci 2007;16:100109.

12 Bechterew W: Studium der Funktionen der Praefrontal- und anderer Gebiete der Hirnrinde vermittelst der associativ-motorischen Reflexe. Schweiz Arch Neurol Psychiatrie 1923;13:61-76.

13 Kesselring J: Constantin von Monakow's formative years in Pfäfers. J Neurol 2000;247: 200-205.

14 Keitel W: Ein Opfer Stalins? Wladimir Michailowitsch Bechterew (1857-1927). Z Rheumatol 2002;61:201-206.

15 Lerner V, Margolin J, Witztum E: Vladimir Michajlovic Bechterev (1857-1927). J Neurol 2006;253:1518-1519.

16 Lerner V, Margolin J, Witztum E: Vladimir Bechterev: his life, his work and the mystery of his death. Hist Psychiatry 2005; 16:217227.
17 Volkov S (ed): Testimony: The Memoirs of Shostakovich. New York, Harper Colophon, 1979.

18 Topolyansky VD: Noch' pered rozhdestvom v 1927 godu. Ogonyek 1989;27:9-10.

19 Demin D: Vrachnebnaya Taina. Moscow, Manskiy, 2002.

20 Vein AA, Maat-Schieman LC: Famous Russian brains - historical attempts to understand intelligence. Brain 2008;131:583-590.

21 Hagner M: Skulls, brains, and memorial culture: on cerebral biographies of scientists in the nineteenth century. Sci Context 2003;16: 195-218.

22 Owen D, Davidson J: Hubris syndrome - an acquired personality disorder? A study of US Presidents and UK Prime ministers over the last 100 years. Brain 2009;132:1396-1406.

23 Owen D: In Sickness and in Power: Illness in Heads of Government in the Last 100 years. London, Methuen, 2009.

24 Bechtereva NP: On the scientific school. Hum Physiol 2004;30:379-391.

25 Bekhterev VM: Immortality from the scientific point of view (translation of speech delivered at St Petersburg Psychoneurological Institute in February 1916). Society 2006;43: 74-80.

26 Grashenkov NI: Relationship between British and Russian medicine and neurology, and the role of the National Hospital, Queen Square, London, in the development of Russian neuropathology. J Neurol Neurosurg Psychiatry 1960;23:185-190. 